\title{
Mid-Victorian England and Female Emancipation: Elizabeth Gaskell's North and South
}

\author{
Saman Ali Mohammed \\ Department of English, College of Language, University of Human Development \\ Sulaimani, Kurdistan Region - F.R. Iraq
}

\begin{abstract}
Victorian era is female emancipation. In the heart of an industrial period when materialism, economic competition and public domain were dominated by men, women had the domestic sphere. The apparent difference between these two spheres was not tolerable for Elizabeth Gaskell and she critiqued it. Her novel North and South discusses the perceptions on women, the idea of industrialization, and class distinction in Victorian Era. Developing her main character Margaret Hale, Gaskell critiques her society and the mentality behind a perception of patriarchal and materialistic society. Gaskell develops her character on many different levels by giving her various roles especially in the industrial north. Valuing certain qualities women possess in the domestic level, Gaskell brings Margaret to the debates, businesses, factories, riots and public sphere of Milton. Gaskell presents the contemporary and Victorian readers with a different perception of women, their roles, and significance in the private and public spheres.
\end{abstract}

IndexTerms_Victorian Era, Materialism, Female Emancipation, Public and Private Spheres.

\section{Early and Mid-Victorian Age and}

\section{Women}

The nineteenth century literature portrayed the perspective on gender and the role of literature expandingly. In the awakening of the century, a dive into human intellectual potential started that commented on almost all the aspects of society, shook the accepted beliefs, broke the social and cultural changes and offered new perceptions. Discussing the roles both genders had, accepted, or suffered or could play in the advancement of society and culture as well as ideas of marriage, independence, virtue, wealth and social status are some of the main topics debated, critiqued and written about throughout the nineteenth century especially the Victorian era. As Nancy Armstrong states:

Marry a man with whom you were emotionally compatible if you could, but marry a man of material means you must, such novels as Pride and Prejudice (1813) and Emma (1816) seemed to say, or else face the degradation of impoverishment or, worse, the need to work for a living. Given that the population under twenty-five years of age shot up from 46 to 58 percent of the population between the mideighteenth century and the beginning of Victoria's reign in 1837 , courtship rituals to ensure that deserving women would meet and win the hearts of eligible men could not have been considered a frivolous activity (97).

The attempts to define gender positions and roles are not bound to only a period or a writer but centuries. The Victorian age was an age of industry and radical changes and its literature reflected such changes. Both Deirdre David and Anna Jones discuss that nineteenth-century authors utilised the medium of literature to comment upon the Victorian society and its evils; their novels also offered thoughts upon how the problems in Victorian England could be resolved. The role of woman and their social status as well as their proper identity are also critiqued $(31,241)$.

Journal of University of Human Development

Volume 5 No. 1(2019); DOI: 10.21928/juhd.v5n1y2019.pp109-118

Regular research paper: Received 16 January 2019; Accepted 10 February 2019; Published 12 March 2019

Corresponding author's e-mail: Saman.mohammed@uhd.edu.iq

Copyright (O2019 Saman Ali Mohammed. This is an open access article distributed under the Creative Commons Attribution License

(CC BY-NC-ND 4.0) 
Like other early-and-mid Victorian novels Elizabeth Gaskell's North and South, published from 1854-1855, critiques industrialization and the role of women and presents revolutionary ideas about the role of women in society in contrast to the domestic conventions of her time. Gaskell introduces the reader to a female character, Margaret Hale who is in problematic social circumstances that radically challenge conventional perspectives about women. This essay examines critical works engaged with critiquing the situation of women in the time of Elizabeth Gaskell and explains how North and South portrays and critiques fundamental tasks and roles that women could take part both in public and private spheres with a special focus on Margaret. This paper attempts at explaining how and why this novel is a representation of women's voice and was an outcry in Gaskell's time. Throughout the early and mid-nineteenth century, women's position in society was usually in the home. A patriarchal society that valued men and gave them a dominant power made women largely victims of such a mentality and as Nancy states:

In the fiction of the Victorian period, gender ceased to be the means of guaranteeing reproduction of the ruling class and provided instead the means of limiting sexual reproduction. Thus, set in opposition to natural desire, or what might be called "femaleness," a woman's display of Victorian femininity marked the difference between middle-class reproductive practices and those specific to the working classes, the Irish, and so-called "native" peoples. Or so we might conclude from comparing Austen's fiction to that of Emily and Charlotte Bronte. (100)

Judy Lown in her Women and Industrialization: Gender at Work in Nineteenth-Century England explains that women were placed as "domestic ideals" which defined them only with roles in "natural caring and nurturing capacities" (4). A belief that came from a deeply established paternalistic ideology restricted women to "housing, child care and procreation," and resulted in women's marginalization from the outside world (141). After Napoleonic Wars which ended in 1815, the political perspective shifted towards domestic issues and "industrialization offered new opportunities for workers but it also created new stresses" that along with many cultural, societal and political issues became the centre of Victorian debates. Furthermore, ideas of "ideals of moral" became heated topics; "self-discipline thus became a crucial a critical engine of social progress and individual stature" (Adams 6). This ideology as Nicola Humble also asserts, resulted in the construction of "separate spheres:" a "public sphere" dominated by men and a "private sphere" for women which defined each of them with specific and different roles based on their sphere (220). This indicates that home was defined as the only natural domain for women and resulted in their status as a "virtual prisoner at home" (220). Such perception of women placed them in a "dependent and powerless position" and limited their access to the outside world (Honeyman 104). In such a situation, women were thought to want to find a husband as a dominant breadwinner who they could in return provide with other physical, emotional and moral needs. Moreover, the earlyand-mid-Victorian mentality did not consider women in equal terms with men but rather as less in terms of physicality as well as intellect and this resulted in restricting women to certain abilities. This ideology not only identified women to home and constrained them from "practicing their profession or acquire the necessary education" but also undervalued their role and "silence[d] their voices" (Basch 105, Levine 7). Thus, it was that the home became, in one of the more delirious celebrations of the ideal, what John Ruskin in Sesame and Lilies called "the place of the peace; the shelter, not only form all injury, but from all terror, doubt, and division" (Ruskin 1903: xviii, 122 qtd Adams 8)

\section{Culture, Industrialization and Home and North and South}

Gaskell from the early chapters of North and South rejects the conventions of her time and provides a revolutionary description of her main character, Margaret Hale, in the south of England in the mid-Victorian time which from an ecofeminism's point of view is self-explanatory taking the agricultural south counted. She separates her heroine from other female characters by giving her distinctive qualities that stand out and are suggestive to be imitated. For instance, before Edith's wedding, while Edith is lying on a sofa, Margaret stands 
a "lay figure" to show the Indian shawls (Gaskell 12). Edith is portrayed as "a soft ball of muslin and ribbon," and Margaret is depicted as "tramp[ing] along in the woods at Helstone" (Gaskell 5, 16). This suggests that Gaskell portrays them differently in contrast to conventions and neither restricts her heroine to subservience nor presents her as a weak figure but rather as an effective and firm one at home. For instance, unlike other ladies in the house, Margaret sees herself as having "the familiar features in the usual garb of a princess" and "stood perfectly still" when Henry Lennox came in whereas other ladies "started back" (Gaskell 12). In such a powerful representation, Gaskell encourages women to have a resolute status and rejects the patriarch mentality and such features, as Barbara Harman supports seems "acutely conscious and thus more appropriately an agent than a mere body emptied of power" (362). By contrasting Margaret with Edith and Lennox, Gaskell provides an indication of her heroine's bold personality and highlights that Margaret is a "conscious and a high spirited" woman whose aim is to oppose patriarchy or at least should be this state in the time of Gaskell (Lansbury 107). If, as James Adams states, "Female tenderness and modesty thus became an emphatically political issue, and a rebuke to men who would presume less of women", Gaskell even denounces that and her presentation speaks so. (85)

Gaskell tests Margaret in the face of all the challenges society put or a woman faces in a deeply stricken industrial world. Margaret grows and North and South can as well be an example of Bildungsroman, the novel of development or education in which "self-discovery and self-definition of the protagonist tend to be more emphatically social, conjured up in large part by new prospects of social mobility, a world of possibility at once exhilarating and fearful." (Adams 123). To subvert the conventional mentality that did not value a woman's ability and influence in social life, Gaskell in chapter seven, moves the novel's setting from the agricultural Helston to the industrial Milton that serves also as a way for Margaret to educate, experience and develop. Rosemarie Bodenheimer agrees that Gaskell through this move critiques the patrician society of her time in the figure of Mr. Hale and leads Margaret to the heart of industrial north (54-55). When Margaret's father decides to move to Milton because he faced ideological problems, he was not able to manage his conscience or explain his situation to his daughter and thus he is dependent on Margaret: "putting his hand on Margaret's arm, he mutually entreated to be led away, as if he were blind and she his faithful guide" (Gaskell 249). Through such scenes one is taken to think through and reflect back on the power of female characters maintaining life, guiding and shielding because Margaret is the one that not only manages the move, but also breaks the news to her mother because her father cannot do it. She also provides morality and support to the Hale family and she has "a masculine quality, one conventionally expected from fathers" (David 13). Margaret is portrayed as a "spirited and strong-minded" character that supports her parents who are left "paralyzed by prospects of this economic, social, and psychological disruption in their lives" despite the industrial world where a woman's effect is denied and devalued (Brown 347). Pasty Stoneman supports this view that Margaret has a "dynamic and independent" character, unlike her contemporaries, and Gaskell shows her significant and essential role that efficiently looks after her family (137). This is an indication of Gaskell's appreciation of a woman's function in managing home space and providing morality to the family, especially when in the early mid-Victorian mentality women were considered as "passive victims suffering under patriarchal social structures" in industrial life (Brown 2).

Gaskell contradicts the binding and restricting of women's access to the domestic world only. For the Victorians the domestic woman "acted as both guidance and balm, a source of value outside the world of exchange. This led to the idea of a woman being associated with an instinctive, well-nigh angelic devotion to the needs of others, and thus a moral influence which elevated and refined those around her" (Adams 8). Yet, Gaskell exposes her heroine to the public world of Milton unlike her contemporaries and this suggests a revolution in her time especially when industrialization had a profound influence in restricting women to the home and caused the rise of a “middle class of separate spheres" (Honeyman 98). In Gaskell’s time, for a woman to be in public was considered "bad publicity" and "walking alone in the streets, speaking before a mixed audience ... engaging in a world of business or politics ... 
might compromise a women's reputation" (Harman 551). In contrast, as a challenge Margaret is placed in the streets of industrial Milton and characterized as strong enough to meet "the future... however, stern and iron it be" (Gaskell 55). Thus, the representation is that women can be in public with men and emphasizes women's rights in public that the "patriarchal values of middle and upper classes" have dominated and this placement of Margaret in Milton challenges the "sharply marked division between private and public life" because a woman's position and her role in public was a matter of anxiety for the early and mid-Victorians (Harman 553, Johnson 1). Moreover, it is almost certain that Gaskell not only provides women with access to be in public with men and tries to free them from restrictions but also "bring[s] to the surface the unconscious bifurcations that produce class and gender ideology" and to have Margaret in public is to destroy such “dichotomies" (Johnson 2).

\section{Elizabeth Gaskell, Margaret Hale and Working Class}

Associating certain female qualities and home, Gaskell takes out such powerful forces to the streets of Milton easing the tension in the industrially stricken and economically challenging climate. Through an industrial theme she shows the influence that women can have in alleviating class tension and working-class suffering. To better portray such influence on the social life of the workers, Margaret is placed between Thornton, an "aggressive northern capitalism" and Higgins, "working class trade unionism" (Johnson 2). The suffering lives of people, as Lown maintains, was a "moral failure" that both caused tension and undervalued women's role and further isolated and restricted them to home (97). Such tension is reflected in Bessy's suffering: "I think if this life is th' end, and that there's no God to wipe away all tears from all eyes-yo' wench, yo'! I could go mad" (Gaskell 95). The condition of the working-class families essentially highlights the evils that materialism and economical tensions have brought to their lives. In such a situation Gaskell not only places Margaret in public, but also depicts her with the role of investigating and observing the working-class conditions as well as having a "moralizing influence" (Elliott 31). Margaret's mediation to class conflicts and suffering is depicted by her constant visits to Higgins family, for instance, after she becomes aware of the condition of poverty, she helps Higgins family with food and comfort. Furthermore, she has a "sympathetic listening and physical and spiritual ministration" on the Higgins family (Parker, "Ladies Business" 329). She reads the Bible to Bessy, befriends Mary, and prevents Higgins from drinking. This shows how North and South is concerned with the influence of "exploring the relationship between women's life and their social environment," freeing them from restrictions and giving them necessary social roles (Dredge 85). Thus, Margaret's skills are valuable both in the public and private spheres. The title of the novel was not North and South first, but "Margaret Hale" after its main character and this change suggests "a larger ambition" since "it undertakes a more comprehensive social portrait, which sets the more tranquil, agrarian south against the frenetic energy and social dynamism of the industrial north" (Adams 152)

In Milton Mr. Hale finds "something dazzling" in the spectacle of so much energy and power as men strive for advancement, economic boost, but are stuck in corruption, failure and dishonesty. Gaskell however through her heroine critiques the evils and fundamental conflicts that industrialization caused and demonstrates the role of women in awakening the community by portraying Margaret to confront Thornton as the embodiment of industrialization. For instance, when Thornton says, "We the owners of capital have a right to choose what we will do with it", Margaret disagrees and sarcastically asks him whether it is "a human right" (Gaskell 139). She does not agree with Thornton and is depicted as having a moral motive and an effective influence on Thornton and his usage of power and wealth. When her father said that he wants to "do justice" to Mr. Thornton, Margaret replied "So I do" (Gaskell 156). She further says "He [Thornton] is my first olive: let me make a face while I swallow it. I know he is good of his kind, and by and by I shall like the kind" (156). This is important since the evil effects of such a materialistic mentality and industrialization are depicted through Butcher and Bessy's death and Higgins' state of constant working and suffering. 
Margaret discovers the destructive influence of materialism and class distinction and awakens Mr. Thornton of them as when Mr. Thornton asks why Margaret complains about living in Milton, she replies: "Because ... I see two classes dependent on each other in every possible way, yet each evidently regarding the interests of the other as opposed to their own; I never lived in a place before where there were two sets of people always running each other down." (111). Effectively women's essential functions in society portrayed through ultimate understanding and certain qualities women possess. Women's role here is profoundly pictured through Margaret that has a profound "moral influence ... indirectly exert on men" like Thornton (Gallagher 168). This achieves two targets of portraying women's effective roles as well as freeing and subverting them from domestic boundaries.

The projection of Margaret is tried to be within the realistic perception of Victorian understanding on women. Margaret continually efforts to restrain her emotions as she is - "vexed and ashamed at the difficulty of keeping her right place, and her calm unconsciousness of heart" (303) - but in the progression fights with "that most difficult problem for women, how much was to be utterly merged in obedience to authority, and how much might be set apart for freedom in working” (203). Gaskell proposes a radical reform of the cooperation of both sexes in public and private lives. For instance, in Gaskell's conventions, philanthropy and "social service" were opportunities for women to access the public (J. Parker 31). She appreciates such social functions but also expects more from women as she portrays Margaret with a crucial role of addressing problems like strike and conflicts between manufacturers and workers. For instance, when Margaret says:" I have heard some people, or, it may be, only someone of the work people, speak as though it were the interest of the employers to keep them from acquiring money - that it would make them too independent if they had a sum in the savings' bank"' (111). Thornton replies, "I dare say it was that man Higgins who told you all this," (111). It is crucial that Margaret interprets between the masters and men and exchanges ideas and opinions, which as Elliot indicates is revolutionary because a woman's participation in the community was denied $(40,41)$. What is more, Margaret learns the language of both masters and men and her mother accuses her of acquiring "factory slang" but she emphatically says "if I live in a factory town, I must speak factory language when I want it ... I could astonish you with a great many words you never heard in your life. I don't believe you know what a knob stick is" (Gaskell 219). Thus, her success and her essential role in the public sphere as a "mediator of social spheres" (Elliot 40). Furthermore, this shows that Gaskell believes in women's essentiality in society and switches their roles from charity activities to "a recognizable civil agency" that places them in the social function of industrial life (Dredge 83-85). Moreover, because capitalism and patriarchal society depreciated and debased certain roles in society but Gaskell through Margaret critiques this.

Margaret's function of what Elizabeth Starr calls a "transformative role" (395) is important because Gaskell is critiquing the conflicts in society by presenting the power that women have to settle such conflicts. Margaret's influence in the "mediation of different opposing interests" is another significant role the mid-Victorian context counted (Elliot 32). The patriarch mentality apparently positions men in "authority" and views women as "supportive" and engaging with "domestic roles" (Honeyman 95). Certain qualities are given to women and thought of home as John Ruskin in Sesame and Lilies called "the place of the peace; the shelter, not only form all injury, but from all terror, doubt, and division" (Ruskin 1903: xviii, 122 qtd Adams 8). Gaskell portrays that it will be a social failure to restrict women in domestic life because of the meaningful and constructive influence women have in public. Margaret is presented as the "worker's advocate, a sympathetic lady ... speaking for these inarticulate masses" (Parker, "Fictional" 322).

In contrast Gaskell provides Margret with an active role of reconciling two different groups in public which is a significant and essential role of management in society especially in an industrial life of early and mid-nineteenth century when women were considered as "passive recipient" and "not valued" (Honeyman 37, 49). For instance, Margaret informs Thornton about his conflict with workers and saying: "I am trying to reconcile your admiration of despotism with your respect for 
other men's independence of character" (Gaskell 116). Thus, Gaskell presents Margaret to "apply a single standard of behaviour to both private relations and relations between classes" (Gallagher 168). Margaret, unlike any other ladies in the novel, argues with Thornton that:

Not in the least because of your labor and capital positions ... but because you are a man, dealing with a set of men over whom you have ... immense power, just because your lives and your welfare are so constantly and intimately interwoven. God has made us so that we must be mutually dependent ... Neither you nor any other master can help yourselves. The most proudly independent man depends on those around him for their insensible influence on his character-his life (114-15).

This confrontation undermines a materialistic society that causes imbalance and tension as it values only "utilitarian pragmatism, self-reliance and material wellbeing" (Brown 345). Moreover, this is a revolutionary and an essential depiction of women with a significant role in the public with men. Having influenced Thornton, Margaret is happy when he admits "What the master is, that will the men be, without overmuch taking thought on his part" portraying her with the role of reconciling between workers and masters (Gaskell 115). This indicates that Gaskell associates Margaret with the role of reconciliation between workers and masters.

Margaret's reconciliation is granted when Mr. Thornton says, "The battle is pretty fairly waged between us" (Gaskell 101). Such an achievement by women is vital since as Elliot further explains, Gaskell is "idealizing ... industrial relations ... [and] advocating a type of social arrangement pioneered by women" and rejects such a position to base on "political economy or other theoretical abstraction" (31). Margaret's profound influence and achievement can be better perceived when Mr Thornton denied it and actually mocked Margaret: "On some future day ... in Utopia this unity may be brought in to practice" (112). In contrast, Margaret had a profound effect on Thornton to finally have a good relationship with workers and her effect is based neither on "rural paternalism" nor on a "cash nexus" but rather a mutual and human understanding (Elliot, 31). Such an effect undermines Thornton's belief and shows Margaret's influence that brings the union of both sides. Margaret's engagement in the public life of Milton is an outcry that "women should be seen not as separate nor as passive or as simple victims, but as vital and essential to the making of industrialization" (Honeyman 37). Gaskell implies that women are crucial in influencing social participation and management as Margaret settles both sides to a mutual social communication and understanding.

\section{Intellect and Awareness}

In contrast to the early and mid-nineteenth century, Elizabeth Gaskell believed in the intelligence and the social awareness of women on public social, political and economic issues. She emphasized that women should have their own voice on such issues, especially as Nancy Henry concedes that industrialization resulted not only in the conception of unregulated wealth, but also the restriction of women to certain household skills (157). To convey such potential role, Margaret is distinguished from other female characters in the novel. For instance, when in Thornton's house, unlike other ladies who are "employing themselves in taking notes of the dinner and criticizing each other's dress", and unlike Mrs. Thornton who is depicted as a prisoner of her "museum like home" (Harman 335), "Margaret caught a clue to the general conversation [among the gentlemen] ... listened attentively" (Gaskell 151-2). Margaret's interests contrast with those of the other stereotypical Victorian ladies and this was revolutionary. Moreover, she is depicted as: "liked the exaltation in the sense of power which these Milton men had" (Gaskell 152). This suggests an equal participation that should be by both men and women in public issues and it is essential especially when women were considered "intellectually limited" which isolated them from the public world of "business, politics and serious intellectual endeavours" dominated by men (J. Parker 33). Margaret is an active woman participant along with Mary Barton, "the mutual attraction of two proud and powerful natures ... alike in their energy and independence" (Gilmour 53). Margaret's distinctive qualities are encouraging women to enact as she is revolting against the conventions of her time and establishes hers. 
Gaskell demonstrates women's consciousness to the public world and legitimizes their intellectual equality and their engagement to a "universe conventionally understood to be without interest for women and ... avoidable to them" (Harman 366). Margaret is depicted as the "novel's center of consciousness" and having "intelligence and self-awareness" that in equal terms expresses her opinion with men about public affairs (Mann 24). For example, Margaret comments on Lennox and Thornton's conversation about the role of a representative saying, "there is a difference between being representative of a city and the representative man of its inhabitant" (Gaskell 308). She effectively states her opinion and negotiates the public issues and her voice is "clear" and "cold" (308). Mr. Bell describes Margaret as "a democrat, a red republican, a member of peace society, a socialist" (217). This description is crucial because comparing Margaret with all the other ladies in North and South, none of them receives such a description. Furthermore, she actively states her perspective about the structure of ruling and power especially when the debates center around whether it is right to treat workers like children to which Thornton believes "despotism" and exercising it "is the best kind of government for them" (Gaskell 141), Margaret asserts her belief that "God has made us so that we must be mutually dependent" (145). Margaret's words depict "motion, flexibility, and elasticity symboliz[ing] her most important mental qualities" (Mann 35). Gaskell rejects women as passive characters in society and depicts Margaret as an energetic and conscious participant who is given both "abstract" and "objective" qualities which mean an ability and an awareness to think "abstractly and disinterestedly about political, social, intellectual, and religious matters" (Mann, 24). Gaskell describes her heroine as: "She herself must one day answer for her own life, and what she had done with it; and she tried to settle that most difficult problem for women, how much was to be utterly merged in obedience to authority, and how much might be set apart for freedom in working" (385). Margaret unconventionally states her viewpoints on public issues equally with men and by providing roles for women in public debates, Gaskell shows a woman's influence and claims "authority for herself and other middle-class women to enter public debates about social and political issues" (Elliot 43, Mann 24). And as Pearl Brown states "Thus, in Margaret, Gaskell has created a character with more than enough of the requisite strengths to take control of her life. In fact, as the daughter of an Anglican clergyman of a poor rural parish, she has had experiences that should have prepared her to forge an independent life for herself' (347)

\section{Active Public Roles and Engagement}

Gaskell legitimizes the public roles for women and contributes them with essential practical roles as Margaret is provided with the role of a "saviour" to the lives of men (Henry 158). This is essential to contrast a patriarch and also a materialistic mentality that equated men with "economic primacy and familial authority" while women narrowly viewed with "domesticity and subservience" (Lown 176). When her brother is in danger of being arrested, Margaret saves him to escape even at the expense of betraying her truthfulness and stands against injustice saying, "Loyalty and obedience to wisdom and justice are fine; but it is still finer to defy arbitrary power, unjustly and cruelly used--not on behalf of ourselves, but on behalf of others more helpless" (Gaskell 102). Furthermore, Margaret's protection of her brother "more than an act of sisterly solidarity is an act of conscience" (Gallagher 175). Unlike her contemporaries that the emergence of a woman in public was to make "a spectacular of oneself, openly elicit notice, to create a stir" (Harman 551), Margaret is characterized differently and acts with "strength and fortitude" (Matus 42). Therefore, Gaskell does not limit Margaret to what Lennex calls "ladies' business" but provides her with "women's work" that rescues the lives of male characters and maintains a balance between both sexes (Gaskell 12). North and South presents Margaret with an "innate goodness" and an "epitome of nobility who ... awakens this embryo goodness in others" which is the product of Gaskell "a humanitarian and a prophetess of distinctly modern social method" (Johnston 225).

Another public action through which Gaskell is able to challenge a woman's role is when Margaret protects Mr. Thornton in the public domain with courage and bravery. When the Milton men strike, unlike his mother, Margaret bravely supports Mr. Thornton saying, "Go down this instant, if you are 
not a coward. Go down and face them like a man" (Gaskell 165). Furthermore, in the middle of the riots Margaret protects Mr. Thornton by "[throwing] her arms around him; she made her body into a shield from the fierce people beyond" with an attitude that conveys the influence of women (Gaskell 166). Such insertion in the novel explains rejection of a mentality of women as "physically delicate," that isolated them from the public world dominated by men (J. Parker 34). On the other hand, although Anne Longmuir believes that Margaret's being in public endangers her morality to be a commodity herself (239), Gaskell portrays Margaret with "public mindedness" and ability to break the conventional boundaries and works beyond the restricted separate sphere (Parker, "Ladies Business" 2). Furthermore, with such an action, a woman's influence is portrayed that makes a cooperative gentleman out of Mr. Thornton that trade and capitalism has hid (Wootton 30). Margaret is "personally disinterested and ... acts out of abstract sense of justice" and makes no difference between her brother and Thornton and the same sense of "authority, justice, and mercy unites the two acts of defiance" based on "abstract ethical judgement" (Gallagher 172,175).

By having such a practical public role, Gaskell tried to influence the social life to "link the public and private realms of existence in action as well as in consciousness" (Gallagher 170). For instance, when Mr. Thornton says "go away, this is no place for you," Margaret emphatically replies "It is!" (Gaskell 167). Such a powerful sense of courage conveys women's role in public management. Sarah Ellis asserts the status of women as "the guardians of the comfort of their homes" which defines women's role better at home and she further identifies women as "make[ing] sacrifice, in order that his [man] enjoyment may be enhanced" (qtd. in Plunkett 75 76). However, the plot in North and South Gaskell portrays the significance of domestic roles as well as acts in public. What is more, Gaskell distorts any ideology to constraint women based on their gender and asserts after Margaret's protection that "If she thought her sex would be a protection ... she had turned away from the terrible anger of these men" (Gaskell 267). This appears as a strong indication that Gaskell claims "an independent and autonomous role" for women that they were deprived from (Elliot 25). Gaskell presents the fundamentality of public engagement but also balance between both sexes. To stand against the mentality of her times towards women, Gaskell not only reverses the "normal sex roles" but also implies that "the inferiority attached by her contemporaries is ... class linked, not sex linked" (Mann 36). Gaskell advocates an "integration of domestic and industrial economies, male and female spheres" (Parker, "Ladies Business" 2).

\section{Geographical Locations}

Throughout the novel the reader can perceive Gaskell's depiction of Margaret's nature and her endurance in the most terrible circumstances and social transformations unlike her conventions. Margaret travels and connects various geographical locations like London, Helston, and Milton (Polland 114). She could adapt herself to these locations specifically the industrial city of Milton and this crucially undermines any perspective that views women as inactive characters of the society and more significantly when she is left parentless and her brother prefers to stay in Spain with his girlfriend. Margaret's boldness is significantly portrayed when Mrs. Thornton tells Margaret that "Milton is not a place for cowards... if you live in Milton, you must learn to have a brave heart" (109). In contrast Margaret replies "I do not know whether I am brave or not until I'm tried" (109). Such voices, which were not expected from household mid-Victorian women, portray a high-spirited mid-Victorian woman and especially when Margaret is left with ultimate independence to such an environment where women's access was limited to domestic life. Margaret survives various confrontations massive pressure when she protects Thornton in public, a noble act of breaking boundaries and endured people's scornful attitudes. Moreover, during events like the death of Mr. Boucher, Bessy and her parents also left Margaret under great pressure that were "demanding internal adjustment and outward moral actions on her part” (Brodetsky 294). Also, Gaskell's fiction emphasizes "open-mindedness, tolerance and sympathy" as essential qualities and thus This Victorian woman is given "tests of courage, physical bravery, and moral choice, physical or mental endurance" (Henry 150, Craik 91). Such 
circumstances are Gaskell's portrayal of a public and difficult world that Margaret left independently to solve internal and external pressures that serve to reveal women's endurance and their necessity to be in public with men (Duthie 112).

\section{Conclusion}

Gaskell's North and South is a true representation of female emancipation and their outcry in the mid-Victorian era through Margaret Hale, Gaskell's heroine. Gaskell essentially critiques women, their social status and their roles in society and the economical and industrial life and analyses the relationship between public and private life of men and women in the early and mid-Victorian society. Gaskell emphasis women role in their domestic life to maintain a stable and a strong family unit. Through her main character, she details that women should be more actively involved in social, political and economic management. She redefines the position of women especially in the public role standing against traditional principles, conventions, and institutions. Gaskell's portrayal of a woman as the central character of her novel is essential as it is a reflection of Gaskell's perceiving the goodness and potentials of the individuals when dealt with well and constructively and creatively made use of the human resources that could win us again and solve many problems. Gaskell, by setting her novel in an industrial environment is emancipating and subverting the traditional notion of women and portrays the fundamental importance of women role in a society which materialism and wealth have its main canons. To Gaskell, women powerfully and independently can also play a crucial part in public with men and the stresses the importance of building a balance between both men and women. Thus, the novel significantly represents the power of female voice and women's indispensability for managing the social and political issues of society. North and South portrays women's desire to free themselves and rejects the notion that women should be only in the private sphere.

\section{References}

Armstrong N. (2006). "Gender and the Victorian Novel”. Cambridge Companion to Elizabeth Gaskell.

Adams J. (2012). A History of Victorian Literature. Blackwell Publishing Ltd.

Basch, F. (1974). Relative creatures: Victorian women in society and the novel, 1837-67. London: Allen Lane.. Print

Brodetsky, T. (1986). Elizabeth Gaskell. Leamington Spa: Berg,. Print Bodenheimer, R. (1979). "North and South: A Permanent State of Change." Nineteenth-Century Fiction 34. 3: 281-301 Web. Jstor. 21 Dec. 2012

Brown, L. P. (2000). “From Elizabeth Gaskell's 'Mary Barton' to Her 'North and South': Progress or Decline forWomen?" Victorian Literature and Culture 28. 2: 345-358 Web. Jstor, 25 Oct 2012

Craik, A. (1975). Elizabeth Gaskell and the English Provincial Novel. London: Methuen. Print

David, D. (1981). Fictions of Resolution in Three Victorian Novels: North and South, Our Mutual Friends, Daniel Deronda. London: Macmillan,. Print

Dredge, S. (2012). 'Negotiating 'a Women Work' Philanthropy to Social Science in Gaskell's North and South." Victorian Literature and Culture 40: 83-97 Web. Project Muse 24. Oct 2012

Duthie, E. (1980). The Themes of Elizabeth Gaskell. London: Macmillan,. Print.

Elliott, D. (1994). "The Female Visitor and the Marriage of Classes in Gaskell's North and South." Nineteenth-Century Literature 49. 1: 21 49. Jstor. Web 21. Oct. 2012

Gallagher, C. (1985). "The industrial reformation of English fiction: social discourse and narrative form, 1832-1867." Chicago; London: University of Chicago Press. Print

Gaskell, E. (2002). North and South. London: Wordsworth Edition Ltd.,. Print.

Gilmour, R. (1986). The Novel in the Victorian Age. Baltimore: Edward Arnold.

Harman L. B (1988). "In Promiscuous Company: Female Public Appearance in Elizabeth Gaskell's "North and South." Victorian Studies 31. 3: 351374 Web. Jstor . 21 Dec. 2012

Henry N. (2007) "Elizabeth Gaskell and Social Transformation" The Cambridge Companion to Elizabeth Gaskell . Ed. Jill Matus. Cambridge: Cambridge. UP, 2007. 148-162. Print

Honeyman K. (2000). Women, gender and industrialization in England, 17001870. Basingstoke: Macmillan,. Print

Humble N. (2009). “Domestic Art.” Cambridge Companion to Victorian Culture. Ed. Francis O’Gorman. Cambridge: Cambridge. UP,. 219231. Print

Johnston J (1928). The Sociological Significance of the Novels of Mrs. Gaskell. 7. 2. 224-227 J stor.

Johnson, P. E (1994). "Elizabeth Gaskell's North and South: A National Bildungsroman." The Victorian Newsletter 85: 1-9 Web. Project Muse 28 Oct. 2012 
Jones A (2009). "Victorian Literary Theory." The Cambridge Companion to Victorian Culture. Ed. Francis O'Gorman. Cambridge: Cambridge UP. 236-254,. Print

Lansbury C. (1975). Elizabeth Gaskell: The Novel of Social Crisis. London: Elek,. Print

Levine P. (1990). Feminist lives in Victorian England: private roles and public commitment. Oxford: Basil Blackwell, 1990. Print

Longmuir A. (2012)."Consuming Subjects: Women and the Market in

Elizabeth Gaskell's North and South." Nineteenth-Century Contexts: An Interdisciplinary Journal, 34:3: 237-252

Lown, J. (1990). Women and industrialization: gender at work in nineteenthcentury England. Cambridge : Polity,. Print

Mann N. (1975). "Intelligence and Self-awareness in 'North and South': a Matter of Sex and Class." Rocky Mountain Review of Language and Literature 29. 1: 24-38. Web. Jstor. 21 Oct 2012

Matus, J. (2007). "Mary Barton and North and South" The Cambridge Companion to Elizabeth Gaskell . Ed. Jill Matus.Cambridge: Cambridge. UP. 27-45. Print

Parker, P. (1997). "Fictional Philanthropy in Elizabeth Gaskell's 'Mary Barton' and 'North and South' ." Victorian Literature and Culture 25. 2: 321-331. Jstor. Web 25 Oct 2012
--- (1997). 'From 'Ladies-Business' to 'Real Business': , Elizabeth Gaskell's Capitalist Fantasy in North and South" Victorian Newsletter 1. 91 1-4 Web

Parker, J (1988). Women and welfare: ten Victorian women in public social service Basingstoke: Macmillan, print

Plunkett, J [et al.] (2011). Victorian literature : a sourcebook. Basingstoke : Palgrave Macmillan, 2011. Print

Polland A. (1965). Mrs. Gaskell: Novelist and Biographer. Manchester: Manchester UP, 1965. Print

Starr, E. (2002). “ 'A Great Engine for Good': The Industry of Fiction in Elizabeth Gaskell's Mary Barton and North and South." Studies in the Novel 34. 4: 385-402. JSTOR .

Stoneman, P. (2007). "Gaskell, Gender, and the Family." The Cambridge Companion to Elizabeth Gaskell. Ed. Matus Jill. Cambridge UP,. 131147

Wootton, S. (2008). "The Changing Faces of the Byronic Hero in Middlemarch and North and South." Romanticism 14.1: 25-35 Web. Project MUSE 21 Dec. 2012. 